Publisher homepage: www.universepg.com, ISSN: 2663-6913 (Online) \& 2663-6905 (Print)

https://doi.org/10.34104/ajpab.020.01390158

American Journal of Pure and Applied Biosciences

Journal homepage: www.universepg.com/journal/ajpab

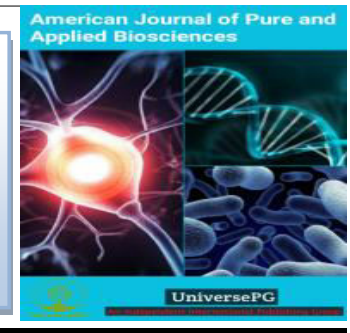

\title{
Arsenic Mitigation Technologies from Ground Water: A Brief Review
}

\author{
Salma Akter Mou' ${ }^{1}$, Md Humayun Kabir ${ }^{1}$, Sabina Yasmin ${ }^{1}$, and Shamim Ahmed ${ }^{1}$ * \\ ${ }^{1}$ Institute of National Analytical and Research Service (INARS), Bangladesh Council of Scientific and Industrial Research \\ (BCSIR), Dhaka, Bangladesh. \\ *Correspondence: shamimchem@yahoo.com (Shamim Ahmed, Principal Scientific Officer, INARS, BCSIR, Dhaka, \\ Bangladesh).
}

\begin{abstract}
Contamination of drinking water due to the presence of as has become a global environmental and socioeconomic threat. The appearance of high Arsenic (As) in drinking water causes a serious health issue around the world. Many countries in different parts of the world have reported high arsenic concentrations. Among all groundwater arsenic contamination affected countries, the position of Bangladesh is the worst. Therefore, it is very important to develop affordable and efficient techniques to remove As from drinking water to protect human health. The most used methods are oxidation, coagulation, adsorption, ion exchange, and membrane technologies. Oxidation is usually used as pretreatment for most of the methods. Coagulation is the most common arsenic mitigation technology in Bangladesh. This technique is effective from $\mathrm{pH}$ 6-8. Ion exchange resins can only remove arsenate. Activated alumina beds work best in slightly acidic waters and usually have much longer run times than ion exchange resins. A cost-effective method for mitigation of As from drinking water is the use of low-cost adsorbent. Membrane methods which are more costly than other arsenic mitigation techniques but very effective where very low arsenic levels are required. Providing a safe water source may not possible in some of the arsenic affected regions or sometimes this process becomes very expensive. Mitigation of As from drinking water may be more appropriate in these situations. This paper presents a review of the conventional methods used for mitigation of As from contaminated drinking water.
\end{abstract}

Keywords: Arsenic, Bangladesh, Contamination, Arsenic poisoning, Human health, and Mitigation technologies.

\section{INTRODUCTION:}

Arsenic is found in the soils, rocks, atmosphere, natural water sources and organisms (Asere et al., 2019). It is 20th in abundance in the earth's crust (Hossain, 2006; Singh et al., 2015). Arsenic is a steelgrey brittle crystalline "metalloid" and a natural constituent with atomic mass 74.9 ; specific gravity 5.73 , melting point $817^{\circ} \mathrm{C}$ (at 28 atm), boiling point $613^{\circ} \mathrm{C}$ and vapour pressure $1 \mathrm{~mm} \mathrm{Hg}$ at $372{ }^{\circ} \mathrm{C}$ (Verma et al., 2014). Arsenic exists in environment in four oxidation states: arsine (III), arsenite (+III), arsenic (0), and arsenate (V) in inorganic forms and the organic forms include monomethylarsonic acid [MMA; $\mathrm{CH}_{3} \mathrm{AsO}(\mathrm{OH})_{2}$ ], dimethylarsinic acid [DMA; $\left(\mathrm{CH}_{3}\right)$ AsOOH], trimethylarsine oxide [TMAO; $\left(\mathrm{CH}_{3}\right)_{3} \mathrm{AsO}$ ], arsenobetaine [AsB; $\left(\mathrm{CH}_{3}\right)_{3} \mathrm{AsCH}_{2} \mathrm{COOH}$ ], arsenocholine (AsC), arsenosugars (AsS), arsenolipids etc. In the inorganic forms, both $\mathrm{As}(\mathrm{III})$ and $\mathrm{As}(\mathrm{V})$ are toxic, both $\mathrm{As}(\mathrm{III})$ and $\mathrm{As}(\mathrm{V})$ exist within the $\mathrm{pH}$ range of 69 (Pinheiro et al., 2017) but As (III) is more toxic than that of $\mathrm{As}(\mathrm{V})$ (Abedin et al., 2002). $\mathrm{As}(\mathrm{V})$ is thermodynamically more stable in toxic (aerobic) 
waters and As(III) in anoxic waters, But they could coexist in both types of waters (Shankar et al., 2014). On the other hand, in case of organic forms the dimethylarsinous acid and monomethylarsonous acid are more toxic than original compounds (Petrick et al., 2000). Four types of As are usually available in groundwater of Bangladesh, these arearsenite $\left(\mathrm{H}_{2} \mathrm{AsO}_{3}\right)$ and arsenate $\left(\mathrm{H}_{2} \mathrm{AsO}_{4}{ }^{-}\right)$(Shankar et al., 2014) and monomethylarsonic acid $\left[\mathrm{CH}_{3} \mathrm{AsO}(\mathrm{OH})_{2}\right]$ as well as dimethylarsinic acid $\left[\left(\mathrm{CH}_{3}\right)_{2} \mathrm{As}(\mathrm{OH})\right]$ (Abedin et al., 2002). At early age when knowledge on the toxicity of arsenicals was very poor, arsenic sulphide (realgar) was occasionally used, both as a medicine and as a poison in Asian civilizations (Abedin et al., 2002). Several As compounds were used as wood preservative, pesticides in agriculture and has also been taken as medicine to treat many diseases like malaria, asthma, leukemia, eczema, chorea, African trypanosomiasis, skin and breast cancers though these uses have become outdated in recent years (Shah, 2012). Arsenic concentration in fresh water represents a health problem, since this element is toxic and carcinogenic in small quantities (Asere et al., 2019).

Arsenic in water is invisible enemy because it does not possess a particular color or taste (Bhowmick et al., 2018). Ingestion of large doses of As could lead to gastrointestinal symptoms, disturbances of cardiovascular and nervous system functions and finally death (Wang et al., 2009). However, intestinal problems are caused because of consuming in determined amounts; long time consumption develops a range of serious diseases such as high blood pressure, skin discoloration, blood vessel diseases, cancer of skin, kidney and lung and reproductive disorders (Smith et al., 2000). The European Union (EU), The United States (US) and The World Health Organization (WHO) have established a value of $10 \mu \mathrm{g} / \mathrm{L}$ as the maximum contaminant level for total As in potable water (WHO, 2011). Due to presence of As in drinking water many countries have faced significant health problems such as arsenicosis which is responsible for various diseases in bladder, skin, kidney and lung. According to WHO $10 \mu \mathrm{g} / \mathrm{l}$ is set as the standard value for arsenic in water (WHO, 2011). But the concentration of arsenic has been found very high in many countries such as Bangladesh (Islam et al., 2017),
India, Vietnam (Berg et al., 2007), China (Yang et al., 2012), Mexico (Armienta and Segovia, 2008), Pakistan (Muhammad et al., 2010), Japan (Ahn, 2011), Korea, New Zealand, Hungary, USA (Haque and Johannesson, 2006), Argentina, Chile, El Salvador, Peru and Nicaragua (Jain and Singh, 2012) WHO reported that at least million people of 50 countries are exposed to arsenic through arsenic-contaminated groundwater at levels above $10 \mu \mathrm{g} / \mathrm{L}$ (WHO, 2011) Bangladesh was detected as one of the worst arsenic-affected countries in the world (Muhammad et al., 2010) in terms of population exposure to arsenic-contaminated water when 400 measurements were carried out in 6 (Smith et al., 2000). In almost half of the measurements, arsenic concentrations were above the maximum permissible limit of $0.05 \mathrm{mg} / \mathrm{L}$ which is safe limit for drinking water in Bangladesh (WHO, 2011). Here about 50 million people being at risk of As exposure. Department of Public Health Engineering (DPHE), Bangladesh, detected four tube wells in Chamagram, Nawabganj that yielded arsenic-contaminated ground water, and in the next year, eight arsenicosis patients were found in the same village (BGS and DPHE 2001). Soon after the identification of arsenic in tube well water, Bangladesh government initiated a number of programs with support from the national and international non-government organizations (NGOs) to determine the extent of arsenic contamination problem (NAISU, 2002). Survey showed that $27 \%$ of the shallow groundwater aquifers have arsenic concentrations greater than $50 \mu \mathrm{g} / \mathrm{L}$ in Bangladesh (Khan et al., 2010).

The percentage seems remarkably low but it is a matter of thought that in Bangladesh, more than $90 \%$ of the rural population gets drinking water from tube wells (Islam et al., 2017). The south and east parts of Bangladesh is the high risk region; here more than $60 \%$ of the tube-wells contain arsenic over $1 \mathrm{mg} / \mathrm{L}$. DPHE randomly checked about 23,000 tube-wells and they identified that the southeast Dhaka was the worst affected area. Almost 20\% of the shallow tube-wells contain As exceeding $50 \mu \mathrm{g} / \mathrm{L}$, which is more than the Bangladesh standard. $80 \%$ of the As-contaminated hand tube wells showed $50 \mu \mathrm{g} / \mathrm{L}$ (Chakraborti et al., 2015). In Bangladesh the As concentration in the groundwater has been found in wide range $(<0.5$ - 
$>4600 \mu \mathrm{g} / \mathrm{L}$ ) (Chowdhury et al., 2018). Different technologies have been implemented for the remediation of arsenic levels in drinking water in many countries (Radloff et al., 2017).

The most commonly used conventional technologies include lime treatment, co-precipitation, coagulationflocculation, oxidation, adsorption, ion exchange resin, membrane techniques, cementation, biological process and emerging technologies (Ahmed et al., 2006; Banerji and Chaudhari, 2016; Gallegos-Garcia et al., 2012; Iervolino et al., 2016; Meher et al., 2015; Yavuz et al., 2010; and Yazdani et al., 2016). There are almost 14 technologies worldwide for the mitigation of arsenic with efficiency varying from $70 \%$ to $99 \%$. One of the most common technologies have been coagulation with metal salts, lime softening, and iron/manganese mitigation. Coagulation processes are sometimes unable to efficiently remove arsenic to permissible levels. Membrane processes have high mitigation efficiency but these methods are highly expensive. In case of Ion exchange process high levels of total dissolved solids, sulphate, fluoride, and nitrate affect the method's efficiency (Lin et al. 2017).

Among all methods adsorption can be considered as a low-cost, simple, and eco-friendly process for Arsenic mitigation. But treatments of natural adsorbents are required to enhance the mitigation efficiency which is very expensive. The aims of the present review is giving a scenario of possible sources of As contamination of groundwater, associated health risks, available technologies for mitigation of As pollution in groundwater, discussion about prospects and limitations of different treatment processes and delineate the areas of further improvement.

\section{Sources of Arsenic}

As released from both geogenic and anthropogenic sources (Alarcón-Herrera et al., 2013). The nature of the aquifers and the process responsible for the As in groundwater has been evaluated in several studies. As is commonly found in several minerals, among these oxides and hydroxides of metals ( $\mathrm{Mn}, \mathrm{Al}$, and $\mathrm{Fe}$ ), sulfides, arsenides, and arsenites are major minerals (Nriagu et al., 2007). Arsenic pyrite is the one of most important mineral source in the ore zones responsible for geogenic contamination of As. The presence of UniversePG I www.universepg.com pyrite in the reduced alluvial aquifers sediments in Bangladesh causes release of As into the environment due to the desorption and dissolution of naturally occurring As bearing minerals (Das et al., 2018). Pyrite is found to be stable under reducing conditions, in presence of aerobic conditions it oxidizes and release As due to formation of iron oxides (Patel et al. 2019). Iron hydroxide acts as a sorbent to increase the amount of dissolved As in groundwater. A number of studies have reported that organic matter enriching fine-grained shale and clay are highly enriched with As (Bayatkashkoli et al., 2017; Reza and Jean, 2012). However, several studies have suggested that iron oxide coated sand and grains of mica of the sediment are the potential adsorbent of As (Freikowski et al., 2013). In the hydro geochemical environment, Arsenic is released under oxidizing as well as reducing conditions, the former is more common (Howladar, 2017; Nicolli et al. 2010; Su et al., 2016).

Under oxidizing conditions, the key mode of As is released by oxidation of As bearing sulfide minerals like arsenopyrite (FeAsS) (Kim et al., 2012; Yoshizuka et al., 2010) and in case of reducing aquifers, As is released by reductive hydrolysis of metal hydroxides (Berg et al., 2007). The principal cause of As release from aquifer sediments is the reductive dissolution of Fe oxides (Guo et al., 2011). The level of $\mathrm{pH}$ in ground water plays an important factor for As enrichment in groundwater (Wang et al., 2019). Positively charged minerals, namely, $\mathrm{Fe}$ or $\mathrm{Al}$ oxides can absorb As easily (Islam, 2004).

At high $\mathrm{pH}$ values, the colloids as well as clay minerals carry the positive charges. The high level of As in groundwater is accompanied by high $\mathrm{pH}$ values ranges from 7.65 to 8.3. High occurrence of $A s$ in the soil might be occurs due to irrigation runoff (Polizzotto et al., 2013) as well as flooding may also be responsible for high As in groundwater ( $\mathrm{Yu}$ et al. 2015). Furthermore, As also increases due to mining activities burning of fossil fuels, use of arsenical fungicides, herbicides and insecticides in agriculture and wood preservatives (Bose and De, 2013). Emission of As takes place in the environment because of volatilization of $\mathrm{As}_{4} \mathrm{O}_{6}$ by burning of coal, which condenses and ultimately transferred into water reservoirs. 


\section{Exposure Pathways and Toxic Effects of Arsenic to Human Health}

Several studies have been carried out to document the toxicity of arsenic and its impacts on human health in various arsenic-contaminated regions around the globe (Engel and Smith, 2004). The main routes of exposure are arsenic contaminated water and food cooked with that water. Water soluble inorganic arsenicals are rapidly absorbed from the gastrointestinal tract (Khairul et al., 2017). Arsenic usually enters the body in the As (III) form through a simple diffusion mechanism. A small amount of As (V) could cross cell membranes through an energy-dependent transport system then it is reduced to As (III) to binds to DNA or protein molecules (Jomova et al., 2011). Arsenic poisoning is undetectable in primary stages and depending on the amount of As consumed, and immune system of the individual, it takes above 8 years to impact health. Recent studies have reported that human intakes of arsenic in a range of $0.05 \mathrm{mgL}^{-1}$ leads to arsenicosis. Arsenic is associated with cerebrovascular disease, cardiac disease, leucomelanosis and hyperkeratosis, diabetes mellitus, pulmonary disease as well as diseases of the capillaries, arteries and arterioles (Fontcuberta et al., 2011).

Chronic arsenic ingestion from drinking water causes several disorders of the digestive system, respiratory system, cardiovascular system, hematopoietic system, endocrine system, renal system, neurological system, and reproductive system (Santra et al., 2013). These diseases ultimately increase the risk for bladder, kidney, liver, lung and lymphatic cancer, and diseases of the blood-vessels of the legs and feet, and possibly high blood pressure. In Bangladesh, several studies reported that about 25 million people of 2000 village areas of Bangladesh are at risk of As contamination and 3695 out of 17,896 people tested are suffering from arsenicosis. A large number of people in rural Bangladesh are becoming affected by the arsenic contaminated groundwater, which they collect from the tube-wells. The rural people are also getting affected due to the consumption of arsenic-contaminated foods, which they produce by using ground water containing arsenic (Huq et al., 2006). Several skin diseases for example, melanosis, hyperkeratosis, keratosis and leucomelanosis, etc., are the most

UniversePG I www.universepg.com common effects of drinking arsenic contaminated water. The other effects are liver enlargement and cirrhosis, peripheral neuropathy, hypertension, chromosomal abnormality, cardiac failure, diabetes mellitus, goiter, skin cancers and gangrene (Yunus et al., 2011).

The prolonged drinking of arsenic-contaminated water has effect on children's cognitive and psychological development (Asadullah and Chaudhury, 2011). Higher fetal loss and infant deaths have also been found in the regions where groundwater is highly arsenic contaminated (Sohel et al., 2010). Arsenic is also known to cause cytotoxicity, epidemiological toxicity and genotoxicity (Gentry et al., 2010, Suzuki et al., 2007). Epidemiological studies on the effects of arsenic consumption from drinking water on public health indicated a carcinogenic effect. Expert's indicated that a concentration level of $50 \mu \mathrm{g} / \mathrm{L}$ could lead to cancer in 1 in 100 individuals. During chronic poisoning, As causes strong pigmentation of hand and foot known as keratosis, and problems in other body system such as respiratory, neurological, high blood pressure, endocrine, cardiovascular and metabolic disorders (Ferlay et al., 2015).

\section{Treatment Technologies for Mitigation of As from Ground Water}

Many conventional and advanced treatment methods have been proposed for mitigating As from ground water under both laboratory and field conditions. Common methods for mitigation of As from contaminated water are use of chlorine, ozone, etc., physical method such as UV treatment, other filtration techniques such as reverse osmosis, membrane filtration, flocculation, adsorption, ion-exchange, etc. The following sections will demonstrate and evaluate some efficient and practical techniques for the purpose of arsenic mitigation. The performance and the deficiency of the existing techniques are further illustrated specifically.

\subsection{Arsenic Mitigation by Oxidation}

A common pretreatment step in most of the arsenic mitigation technologies is the oxidation of As (III) to As (V) because As (III) is the pre-dominant form of arsenic at neutral $\mathrm{pH}$ and adsorption of As (V) onto solid surfaces is easier than As (III) (Sharma et al., 
2007). Thus, oxidation followed by adsorption is thought to be efficient for the mitigation of As (Leupin and Hug, 2005).

$$
\mathrm{H}_{3} \mathrm{AsO}_{4}+2 \mathrm{H}^{+}+2 \mathrm{e}^{-} \rightarrow \mathrm{H}_{3} \mathrm{AsO}_{3}+\mathrm{H}_{2} \mathrm{O}
$$

Arsenite could be oxidized by atmospheric oxygen, ozone or chemical oxidants. Chlorine, chlorine dioxide, hypochlorite, hydrogen peroxide, Fulton's reagent and potassium permanganate are usually applicable in this purpose, due to low cost and ease of availability (Lee et al., 2003).

$\mathrm{H}_{3} \mathrm{AsO}_{3}+1 / 2 \mathrm{O}_{2}=\mathrm{H}_{2} \mathrm{AsO}^{4-}+2 \mathrm{H}^{+}$

$\mathrm{H}_{3} \mathrm{AsO}_{3}+\mathrm{HClO}=\mathrm{HAsO}_{4}{ }^{2-}+\mathrm{Cl}^{-}+3 \mathrm{H}^{+}$

$3 \mathrm{H}_{3} \mathrm{AsO}_{3}+2 \mathrm{KMnO}_{4}=3 \mathrm{HAsO}_{4}^{2--}+2 \mathrm{MnO}_{2}+2 \mathrm{~K}^{+}+$ $4 \mathrm{H}^{+}+\mathrm{H}_{2} \mathrm{O}$

54-57\% of As (III) can be oxidized to As (V) in contaminated water with air and $\mathrm{O}_{2}$ but complete oxidation (III) can be performed with ozone (Dodd et $a l .$, 2006). But this process is very expensive due to high energy input and mitigation of residual ozone and toxic. In general, oxidation with atmospheric air is a very slow process compared to chlorine and permanganate under wide range of conditions. However, chlorine dioxide is prohibited to use for surface water, American environmental agencies pay much attention to this factor. Chloroamine and hydrogen peroxide are slower than permanganate, chlorine and ozone. It is accepted that free Chlorine or hypochlorite is very effective for the oxidation of As (II), while the oxidation of As (III) is well achieved by ozone. However, chlorine dioxide is prohibited to use for surface water, American environmental agencies pay much attention to this factor. When manganese dioxide coated sand is combined with Fe containing compounds, this becomes efficient oxidizing agents because the treated products are easy to handle but in this process another treatment step is required for the mitigation of $\mathrm{Mn}$ from water. About the mitigation of arsenic, utilizing $\mathrm{FeO}_{4}{ }^{2-}$ for purifying water is recommended HFO (hydrous ferric oxide) appears to be the most important phase responsible for removing the arsenic from drinking water around the world. It is well documented that High arsenic came into contact with iron oxides in the shallow aquifer, which could possibly lead to arsenic mitigation.

Thus, oxidation is very effective process for the UniversePG I www.universepg.com mitigation of arsenic from water. Interfering particles present in water such as $\mathrm{Fe}$ (II), Mn (II), sulfide (HS and $\mathrm{S}^{2-}$ ), total organic carbon (TOC) and dissolved organic carbon affect this process. Due to presence of $\mathrm{S}^{2-}$ and TOC, the oxidation rate of As (III) by ozone decreases significantly (Dodd et al., 2006). Thus, for the appropriate selection of oxidizing agents to accomplish high mitigation efficiency by oxidation it is very important to consider hydrophite chemistry and water composition.

\subsection{Solar Oxidation Technique}

In several studies photochemical and photocatalytic oxidation of As (III) has been investigated. UV irradiation increases the oxidation rate of As (III) with oxygen. This procedure can be catalyzed using sulfite, ferric iron or citrate. In case of solar light hydroxyl radicals generate by the photolysis of Fe (III) species. The oxidation rate is catalysed in presence of hydroxyl radicals. When As contaminated water in perchlorate and perchloric solution at $\mathrm{pH} 0.5-2.5$ was treated with $\mathrm{Fe}$ (III) followed by exposure to solar light the rate of mitigation of As increases. If lemon juice is applied after exposoure of solar light the mitigation rate of As from water becomes higher because the reaction of lemon juice (citrate) with strongly oxidizing radicals produces further radicals (Lara et al., 2006). Adsorption of As on $\mathrm{TiO}_{2}$ after the oxidation of As (III) to As (V) by photocatalytic oxidation and $\mathrm{TiO}_{2}$ was also investigated in several studies. This process can reduce arsenic levels to less than the standard limit given by WHO for drinking water (Miller et al., 2011). A TiO impregnated chitosan bead (TICB) was synthesized and used for mitigation of As from aqueous solution. This study suggested that in the presence of UV light, a larger amount of As is adsorbed due to the increase of the surface area of the TICB and $\mathrm{TiO}_{2}$ was able to photo-oxidize more As (III) to As (V) when comparing with the solution that was not exposed to UV light. In another study, nano-crystalline $\mathrm{Al}_{2} \mathrm{O}_{3}$ and $\mathrm{TiO}_{2}$ impregnated chitosan was prepared for As mitigation (Yamani et al. 2012). Several factors such as the initial As concentration, $\mathrm{pH}$, the presence of natural organic matter (NOM) and anions also influenced the rate of As (V) adsorption on $\mathrm{TiO}_{2}$ (Bang et al., 2005, Miller et $a l ., 2011$ ). When a very low amount of $\mathrm{TiO}_{2}$ is present the $\mathrm{TiO}_{2} / \mathrm{UV}$ system has an inefficient As mitigation 
due to incomplete oxidation (Guan et al., 2012). In addition, an acidic $\mathrm{pH}$ was more effective for adsorption of As (V) on the $\mathrm{TiO}_{2}$ surface (Dutta et al., 2004). Presence of silicate, fluoride and phosphate bicarbonate affect the photocatalytic oxidation of As (III), and adsorption of As on the $\mathrm{TiO}_{2}$ based adsorbent (Guan et al., 2012). Moreover, the treatment required for mitigation of arsenic residues is very complex. Due to several limitations, only oxidation is not considered as a highly effective procedure for mitigation of As.

\subsection{In-Situ Oxidation}

In the in situ oxidation process of arsenic and iron, the tube well water is allowed to oxygenate arsenite to arsenate by the oxygen which is present in the air and the ferrous iron in the aquifer is oxidized to ferric iron (Nicomel et al., 2016). This leads to a reduction in arsenic content in tube well water. The oxygenated water which containing As, and iron is flow back into the same tube well. When water is extracted again from the tube well, the concentration of arsenic will be low due to underground-precipitation and adsorption on ferric iron. The probable reactions of hydrous iron oxide with arsenate are shown below.

$\mathrm{Fe}(\mathrm{OH})_{3}(\mathrm{~s})+\mathrm{H}_{3} \mathrm{AsO}_{4} \rightarrow \mathrm{FeAsO}_{4} \cdot 2 \mathrm{H}_{2} \mathrm{O}+\mathrm{H}_{2} \mathrm{O} \ldots \ldots$ (7)

$\mathrm{FeOH}^{\mathrm{o}}+\mathrm{AsO}_{4}{ }^{3-}+3 \mathrm{H}^{+} \rightarrow \mathrm{FeH}_{2} \mathrm{AsO}_{4}+\mathrm{H}_{2} \mathrm{O}$

$\mathrm{FeOH}^{\mathrm{o}}+\mathrm{AsO}_{4}{ }^{3-}+2 \mathrm{H}^{+} \rightarrow \mathrm{FeHAsO}_{4}{ }^{-}+\mathrm{H}_{2} \mathrm{O}$

This process is suitable where the source of water is tube well or deep wells and others. To avoid contamination of the subsurface by introducing microbes from the surface care must also be taken. Some pore spaces may also become clogged with precipitates if dissolved iron levels are high in water. The potentiality of this process for the mitigation of arsenic is little; the results also indicate that arsenic concentrations can be minimized in the groundwater zone before water extraction (Sharma et al., 2007).

\subsection{Arsenic Mitigation by Biological Oxidation}

Several bacteria known as arsenate respiring bacteria (ARD) may couple anaerobic oxidation of organic substrates to the reduction of arsenates such as Geospirillum arsenophilus, Geospirillum barnesi, Desulfutomaculum auripigmentum, Bacillus arsenicselenatis, and Crysiogenes arsenatis (Oremland et al., 2009). Due to formation of undesirable byproducts,

UniversePG I www.universepg.com application of chemicals in drinking water treatment is often discouraged. Several species of bacteria have been applied to carry out biological oxidation of As. Bacterial activity acts as catalyst to remove the arsenic from water. Some microorganisms such as Gallionella ferruginea and Leptothrix ochracea accelerate bioticoxidation of iron (Katsoyiannis et al., 2004; Ekhlas et al., 2014). Iron-oxides and micro-organisms were settled in a filter medium, which has a adjuvant environment for the adsorption of arsenic. These microorganisms oxidize As (III) to As (V), which adsorbed on $\mathrm{Fe}$ (III). This leads to up-to $95 \%$ mitigation of arsenic. Bacterial oxidation of As (III) followed by mitigation of As (V) by sorption onto biogenic manganese-oxides was also studied (Sharma et al., 2007).

Biological oxidation is a new technique of the oxidation of iron and manganese as a treatment technique for arsenic mitigation (Sanjrani et al., 2019). These biological treatment techniques are the natural biological processes, and it takes a couple of days for remediation of metals in soil and groundwater by certain plants and microorganisms. During treatment, the following sequences of reactions have taken place in the treatment system:

a) $\mathrm{Fe}$ (II) to $\mathrm{Fe}$ (III) and $\mathrm{Mn}$ (II) to $\mathrm{Mn}$ (IV) (oxid.).

b) As (III) to As (V) (oxidation).

c) $\mathrm{MnO}_{2}$ (Precipitation).

d) Abiotic-oxidation of As (III) by $\mathrm{MnO}_{2}$.

e) As (V) sorption via $\mathrm{MnO}_{2}$

This natural process for treatment can lead to up-to 95\% of the mitigation of arsenic (Pallier et al., 2010). Mitigation of As (III) and As(V) from groundwater by biological oxidation of dissolved $\mathrm{Fe}$ and $\mathrm{Mn}$ in a pipe reactor (PR), followed by microfiltration (MF) was also studied. The latest PR-MF process is very efficiently removes $\mathrm{Fe}, \mathrm{Mn}$, and As without application of toxic chemicals for oxidation purpose or $\mathrm{pH}$ adjustment and there is no need of regeneration or backwashing and follows the principles of green chemistry.

\subsection{Arsenic Mitigation by Coagulation-Flocculation}

Coagulation followed by flocculation is another widely used treatment for the mitigation of arsenic from ground water (Andrianisa et al., 2008; Baskan and Pala 
et al., 2010; Lakshmanan et al., 2010; Lacasa et al, 2011). It is commonly used for larger capacity facilities and it requires the production of a floc used to mitigate As from groundwater. Among other various chemical coagulants, this process usually requires $\mathrm{Fe}$ and Al based coagulants i.e. ferric chloride, ferric sulfate, aluminium sulfate. These chemicals need to be added and dissolved in water under efficient stirring for 1-10 minutes. In this process, Cationic coagulants have to decrease the negative charge of colloids and aggregation of particles forms larger particles (Choong et al., 2007). More than $90 \%$ of As (V) and $77 \%$ of As (III) can be removed by this technique. Oxidation of As (III) to As (V) with the addition of hypochlorite or potassium permanganate is required for effective mitigation. Aluminium chloride and polyaluminium chloride are able to reduce the concentration of As below the MRL (Hu et al., 2012). When kaolinite and $\mathrm{FeCl}_{3}$ are used as a coagulant/flocculent, mitigation efficiency is over $90 \%$ and $77 \%$ for As (V) and As (III), respectively (Pallier et al., 2010). Fe based coagulants have been found to be most efficient in water treatment than the $\mathrm{Al}$ based coagulants (Katsoyiannis et al., 2004).

For efficient mitigation of arsenic from water, the arsenic needs to be adsorbed on amorphous metal hydroxides formed from coagulant. The rate of As mitigation is dependent on the quality and $\mathrm{pH}$ of the water before coagulation. The presences of organic matter in groundwater also affect the mitigation efficiency of this technique. The optimum mitigation was observed at $\mathrm{pH}$ below 8.5. There is critical limitation in the process of coagulation/flocculation; it produces a large amount of sludge along with a big concentration of arsenic. The management of this sludge is required to prevent the impact of secondary pollution of the environment and the treatment procedure of sludge is expensive (Mondal et al., 2013). Moreover, in many cases it becomes difficult to lower the arsenic concentration to the acceptable level by this technique (Shakoor et al., 2017).

\subsection{Adsorption}

Adsorption is a simple process in which water is flown through a packed bed of solid adsorption media filled in a column (Shakoor et al., 2017). Solutes adsorb on

UniversePG I www.universepg.com the adsorbent surface and its concentration become reduces in the solvent (Dong et al., 2009; Ungureanu et al., 2015). For treating arsenic contaminated water, activated carbon, Iron-based adsorbents, and low-cost materials such as agricultural wastes and byproducts industrial waste and byproducts, mud, etc. have been used as adsorbents (Ranjan et al., 2009; Haque et al., 2007; Khosa et al., 2014; Chutia et al., 2009; Banerjee et al., 2008; Sasaki et al., 2009; Liu et al., 2012; Zongliang et al., 2012). Nanoparticles and nanomaterial based absorbents have also been investigated for the mitigation of arsenic such as zero valent iron (ZVI) nanoparticles, cupric oxide nanoparticles, titanium oxide nanoparticles, iron oxide based nanoparticles, zirconium oxide nanoparticles, During the flow of water through adsorbent column, arsenic in water are adsorbed onto the surfaces. Due to its several advantages, adsorption is the most widely used technique for arsenic mitigation such as, relatively high arsenic mitigation efficiencies, easy operation, and handling, cost-effectiveness, and no sludge production (Anjum et al., 2011; Jang et al., 2008). The mitigation efficiency of this method depends on the surface area, particle size, pore characteristics, density, zeta potential, mineralogy, characteristics of the surface functional groups, etc. of the adsorbent and the such as temperature, $\mathrm{pH}$, arsenic concentration and ionic strength of the solution (Giménez et al., 2010; Zhu et $a l ., 2014)$. The rate of arsenic adsorption and capacity adsorbents further depend on the presence of other ions such as: silicate, phosphate, $\mathrm{HCO}_{3}{ }^{-}$, and $\mathrm{Ca}^{2+}$.

\subsubsection{Activated Carbon}

Activated carbon is graphite with amorphous structure with a wide range of pore sizes. Activated carbon is used either in powdered or granular form for arsenic mitigation. Ancient Hindus in India used Charcoal for filtration of drinking water and carbonized wood was a purifying agent and medical adsorbent in Egypt by 1500 b.c. Bone-char was replaced by activated carbon in sugar refining in 1901. Activated carbon was first used in the US for treatment of water in 1930. Arsenic adsorption onto pure activated carbon is very poor and regeneration is also difficult, so it is not directly applied for water treatment (Daus et al., 2004).

Increase of arsenic absorption capacity by activated carbon could be achieved when it is treated with 
various metal compounds. Impregnating iron compound onto activated carbon and treatment of activated carbon with $\mathrm{Zr}$ are two way in this purpose. The latter was not suitable for drinking water because of toxic nature. Active carbons are prepared from bones, coconut shells, bagasse, carbon cobs, cereals blood, coal, coffee beans, bark, fish, fertilizer waste slurry, wood, coal, lignite, coconut shell peat etc (Deng et al., 2016). Adsorption capacity depends on activated carbon properties, adsorbate chemical properties, temperature, $\mathrm{pH}$, ionic strength, etc. Although availability of activated carbons, this process remains expensive and vast quantities of activated carbon is required (Ahmad et al., 2018).

\subsubsection{Activated Alumina}

Activated alumina (AA) successfully removed arsenic from ground water (Xie et al., 2013). Activated alumina is a granulated form of aluminum oxide $\left(\mathrm{Al}_{2} \mathrm{O}_{3}\right)$ having good sorptive surface. This is an effective medium for arsenic mitigation from water with high dissolved solid content (Golami et al., 2009). The mechanisms of arsenic mitigation are similar to ion exchange resin, and are often collectively referred to as 'adsorption'. Its efficiency is greater than $95 \%$ under acidic conditions when Alumina surface is protonated. This process is controlled primarily by $\mathrm{pH}$ and mitigation capacity is effective in the narrow $\mathrm{pH}$ range from 5.5 to 6.0 where the alumina surfaces are protonated. Above $\mathrm{pH} 8.5$, Arsenic mitigation capacity is reduced to only $2-5 \%$ of capacity at optimal $\mathrm{pH}$. Therefore, $\mathrm{pH}$ adjustment is required for efficient arsenic mitigation from neutral and basic waters. For arsenic mitigation, fine (28-48 mesh) particles of activated alumina are commonly used. Arsenic adsorbed on the alumina surface during the flow of water through surface. After that column becomes saturated first at upstream zone later at downstream zone and finally it is completely saturated. The advantages of activated alumina are that it requires no chemical addition, it can treat thousands of bed volumes before breakthrough, and filters could be operated for months before the media need to be regenerated.

Regeneration of saturated alumina is done by exposing the medium to $4 \%$ caustic soda, $\mathrm{NaOH}$, resulting caustic waste water with high arsenic content. After washing out of the residual caustic soda, $2 \%$ solution UniversePG I www.universepg.com of sulfuric acid is used to neutralize the medium. During regeneration, the efficiency of the regenerated medium is decreased by $30-40 \%$. If aluminium based sludge is produced during rinsed with sulfuric acid, this sludge will contain a high amount of arsenic because of its arsenic adsorption characteristics. This sludge and the remaining liquid fraction of the solution will require disposal because both residuals contain arsenic. When the AA has reached the end of its useful life, the media itself will also become a solid residual that must be disposed (Tripathy and Raichur 2008).

\subsubsection{Natural Wastes and Agriculture Wastes}

The adsorption technique using agricultural waste has been investigated as a cost-effective method for the mitigation of arsenic in wastewater. Lignin and cellulose in agricultural material contained aldehydes, ketones, carboxylic, alcohols, ether and phenolic groups, which may bind heavy metal ions through complex formation (Ahluwalia et al., 2005). The technique has advantages over others due to simplicity, low cost, high efficiency, flexibility and recovery (Gueye et al., 2016). Different agro-wastes are used as adsorbents for heavy metal mitigation such as orange peel, sawdust (Memon et al., 2008), banana peels (Israt et al., 2008), potato peel, rice straw, seaweed (Basha et al., 2008), wood and bark, tea waste (Malkoc et al., 2007), maize corn cob, jatropha oil cake, sugarcane bagasse (Garg et al., 2007), tamarind hull (Verma et al., 2006), rice husk, saltbush (Sawalha et al., 2005), marine algal biomass, olive pomace, activated sludge, sugar beet pulp, wool, olive cake, sawdust, pine needles, almond shells, cactus leaves and charcoal, seafood processing waste sludge and pine bark (Charlet et al., 2007). The fresh agro wastes were washed with distilled water to remove all dirt, cut into smaller sizes and air dried to remove the free water before oven dry. Then dried in oven at $100^{\circ} \mathrm{C}$ for 24 hours and homogenized in a blender to utilize as an adsorbent.

\subsubsection{Ion Exchangers}

Ion exchangers are also used for mitigation of As from water (Oehmen et al., 2006). Tetrahedron ion exchange resin filter tested under rapid assessment program in Bangladesh (BAMWSP et al., 2001) showed promising results in arsenic mitigation. In ion 
exchange, through dissolved ion the reversible displacement occurs of an ion that will adsorb on the surface of solid materials. For the treatment of As strong base anion exchange resins are commonly used where the oxyanionic species of arsenate are effectively exchanged with the anionic charged functional group of the resin (Chang et al., 2010). Thus produces effluents with low concentration of As (V) (Choong et al., 2007). Sulfate, phosphate and nitrate are mostly used for the mitigation of As via ion exchange. In case of arsenite oxidation of As (III) to $\operatorname{As}(\mathrm{V})$ is an important pretreatment step for ion exchange processes because arsenite usually exists as a neutral molecule. In this process at first the resin bed are usually flowed through $\mathrm{HCl}$ to implant labile $\mathrm{Cl}^{-}$on the surface of resin, which is later exchanged with As. Thus, the effluent contains a large amount of $\mathrm{Cl}-$ and additional step is needed to enhance the quality. The arsenic exchange and regeneration equations with common salt solution are as follows:

Arsenic exchange: $2 \mathrm{R}-\mathrm{Cl}+\mathrm{HAsO}_{4}{ }^{2-}=\mathrm{R}_{2} \mathrm{HAsO}_{4}+2 \mathrm{Cl}^{-}$

Regeneration: $\mathrm{R}_{2} \mathrm{HAsO}_{4}+2 \mathrm{~N}^{+}+2 \mathrm{Cl}^{-}=2 \mathrm{R}-\mathrm{Cl}+\mathrm{HAsO}_{4}{ }^{2-}$ $+2 \mathrm{Na}^{+}$

Where R stands for ion exchange resin.

There are several disadvantages of this process such as. During the presence of sulfate in the treated water exchange of sulfate is more preferable than As for commercial resins. Additionally, impedence of the resin takes place due to iron precipitation and solid particles in aqueous solution. So the resin becomes exhausted, it needs to be regenerated which increases the cost of operation. Due to the generation of large quantities of toxic sludge and is considered as a more expensive treatment compared with other techniques (Ahmad et al., 2017). Moreover, during regeneration of resins, As rich brine solutions are produced which may again lead to environmental release of As (Cundy et al., 2008).

\subsection{Membrane Filtration}

Membrane filtration technique is also used for the mitigation of arsenic from groundwater. Membranes are synthetic materials having billions of pores serving as selective barriers which allow some dissolved compounds to pass through but retains contaminants. Pressure difference between the feed and the permeate sides is the driving force which is needed to transport the water through the membrane. There are two types of pressure-driven membrane filtrations: (i) lowpressure membrane processes, such as ultrafiltration (UF) and microfiltration (MF); and (ii) high-pressure membrane processes, such as nanofiltration (NF) and reverse osmosis (RO) (Shih, 2005).

These Separation processes mostly depend on the the membrane's pore size and increasing driving pressure increases the selectivity of the processes. Separation is accomplished via mechanical percolation for MF and UF membranes while, capillary flow or diffusion is responsible for the separation by NF and RO membranes (Shih, 2005). The size of the soluble As are small enough to pass through the MF membrane. Thus the efficiency of the process is highly dependent on the size distribution of As bearing particles in water (Shih, 2005) for improving the mitigation efficiency, such as coagulation and flocculation (Singh et al., 2015). The mitigation of As using flocculation followed by $\mathrm{MF}$ was better than flocculation sedimentation when $\mathrm{FeCl}_{3}$ and $\mathrm{Fe}_{2}\left(\mathrm{SO}_{4}\right)_{3}$ are used as flocculants. But adsorption of As on the Fe (III) complex was interfered by the $\mathrm{pH}$ and other ions present in solution. UF is also a low pressure technique which is alone not effective for mitigation of As due to large membrane pores (Velizarov et al., 2004). The membrane's pores are not sufficient small to remove the dissolved As in water. As a result, surfactant-based separation processes such as micellar-enhanced ultrafiltration (MEUF) can be utilized to increase the mitigation of As (Iqbal et al., 2007). Micelles are formed after the adsorption of As onto the surface of the cationic surfactant, which are removed by UF. The study conducted by (Brandhuber and Amy 2001) found a moderate rejection of $65 \%$ and 53\% for As (V) and As (III), respectively. Among different cationic surfacetants hexadecylpyridinium chloride (CPC) showed the highest mitigation efficiency, i.e., 96\%. However, the mitigation of As was depended on the $\mathrm{pH}$ of the solution, the initial As concentration and the presence interfering particles (Mondal et al., 2013).

\subsection{Reverse Osmosis}

Reverse Osmosis is high pressure technique and able to remove dissolved As from water to an appreciable 
level (Figoli et al., 2010). Both As (V) and As (III) can be effectively removed (up to $99 \%$ ) from water RO membranes (BAMWSP et al., 2001). Here size exclusion regulates the separation and not the charge interaction. Charged membranes generally have a higher rejection for charged solutes than for noncharged solutes (Seidel et al., 2001). The size of pore of the membrane does not have a significant effect on As rejection, but rather charge exclusion is predominant over the size exclusion mechanism. RO membranes are non-porous so transport of the solvent occurs through the free volume between the segments of the polymer of which the membrane is composed. These membranes are used for water desalination and low molecular mass compounds can be highly rejected (Velizarov et al., 2004). It was shown that the mitigation efficiency for As (V) exceeded $85 \%$ while that of As (III) was far too low (Uddin et al., 2007). In case of RO membranes initial concentration of As had no effect on the removal rate but the removal of As was affected by the $\mathrm{pH}$ of the solution and operating pressure. The effect was much higher for As (III) than As (V). Yoon et al. (2009) concluded that mitigation of As (III) below pH 10 was low because of the existence of uncharged As (III) species in solution. When As (III) was the dominant As species, the mitigation efficiency of As from ground water became less than $50 \%$ (Walker et al., 2008). Therefore, RO is not effective for As contaminated water where As (III) is dominanted. Oxidation is required as a pretreatment step to mitigate total As at the desired concentration. As RO is very expensive, it is not favorable in developing countries (Uddin et al., 2007).

\subsection{Nano-Filtration}

$\mathrm{NF}$ is suitable for the mitigation from water of dissolved compounds with a molecular weight above 300 $\mathrm{g} / \mathrm{mol}$ (Seidel et al., 2001). In neutral and alkaline solution NF membranes are generally possesses negatively charged. Here separation of As is occurred due to electrostatic repulsion between the anionic As species and the charge of membrane (Velizarov et al., 2004). NF is more sensitive than RO with respect to $\mathrm{pH}$ and the solution's ionic strength. The rejection of As (V) was better than As (III) and As (III) could not be reduced to MCL (Uddin et al., 2007). Thus oxidation of As (III) to As (V) is required pretreatment step. Saitua et al. (2005) found that As rejection was independent of transmembrane pressure, cross-flow velocity as well as temperature. But a recent study demonestrated that the efficiency of As (V) mitigation increased with increase of $\mathrm{pH}$, decrease of operating temperature and the initial As concentration (Figoli et al., 2010). Although NF gives desired results in mitigation of As (V) from solution, the problem of this technique is the mitigation of the uncharged As (III) species in the near neutral $\mathrm{pH}$ range. Thus, without oxidative pretreatment, NF is not enough to remove total As (Uddin et al., 2007).

\section{Comparison between Different Techniques}

Many factors can affect arsenic mitigation efficiency including arsenic concentration, speciation, $\mathrm{pH}$ and cooccurring solutes. Therefore, any method should be tested using the actual water to be treated, before implementation of arsenic mitigation systems at the field scale.

Table 1: summarizes the comparison of some effective available techniques on the basis of expense, suitability and percentage of arsenic mitigation.

\begin{tabular}{|c|c|c|c|c|c|c|c|}
\hline \multicolumn{2}{|c|}{ Techniques } & $\begin{array}{c}\text { Removal } \\
\text { efficiency of } \\
\text { As (III) }\end{array}$ & $\begin{array}{c}\text { Removal } \\
\text { efficiency of As } \\
\text { (V) }\end{array}$ & $\begin{array}{l}\text { Relative } \\
\text { Cost }\end{array}$ & $\begin{array}{c}\text { Operating } \\
\text { skill }\end{array}$ & $\begin{array}{l}\text { Sludge } \\
\text { disposal }\end{array}$ & $\begin{array}{l}\text { Pretreatment } \\
\text { required }\end{array}$ \\
\hline \multicolumn{2}{|l|}{ Oxidation } & $\begin{array}{l}\text { Less than } \\
30 \%\end{array}$ & $60 \%$ to $90 \%$ & low & Low & Yes & Yes \\
\hline \multirow[t]{2}{*}{$\begin{array}{l}\text { Coagulation } \\
\text { flocculation }\end{array}$} & Iron & $\begin{array}{l}\text { Less than } \\
30 \%\end{array}$ & Greater than $90 \%$ & \multirow[t]{2}{*}{ high } & \multirow[t]{2}{*}{ High } & \multirow[t]{2}{*}{ produces toxic sludges } & \multirow[t]{2}{*}{ Yes } \\
\hline & Alum & $60 \%$ to $90 \%$ & Greater Than $90 \%$ & & & & \\
\hline \multicolumn{2}{|c|}{$\begin{array}{l}\text { Ion exchange } \\
\text { adsorption }\end{array}$} & $\begin{array}{l}\text { Less than } \\
30 \%\end{array}$ & Greater than $90 \%$ & high & High & $\begin{array}{l}\text { Solid sludge disposal } \\
\text { problem }\end{array}$ & No \\
\hline \multicolumn{2}{|l|}{ Membrane } & $60 \%$ to $90 \%$ & $60 \%$ to $90 \%$ & high & Medium & No sludge disposal & Yes \\
\hline
\end{tabular}




\begin{tabular}{|c|c|c|c|c|c|c|}
\hline Techniques & & & & & problem & \\
\hline Activated carbon & $\begin{array}{l}\text { Less than } \\
30 \%\end{array}$ & Greater than $90 \%$ & low & Low & $\begin{array}{l}\text { No sludge disposal } \\
\text { problem }\end{array}$ & \\
\hline Activated alumina & $60 \%$ to $90 \%$ & Greater than $90 \%$ & Medium & Low & Toxic solid waste & Yes \\
\hline Natural waste & - & $22.8 \%$ to $82 \%$ & Low & Low & $\begin{array}{l}\text { No sludge disposal } \\
\text { problem }\end{array}$ & no \\
\hline In situ oxidation & $60 \%$ to $90 \%$ & Greater than $90 \%$ & Medium & Medium & No arsenic-rich wastes & \\
\hline Precipitation & $\begin{array}{l}\text { Less than } \\
30 \%\end{array}$ & Greater than $90 \%$ & Low & Low & $\begin{array}{l}\text { No sludge disposal } \\
\text { problem }\end{array}$ & Yes \\
\hline Reverse Osmosis & $60 \%$ to $90 \%$ & $60 \%$ to $90 \%$ & High & High & $\begin{array}{l}\text { No solid waste. } \\
\text { Removes other } \\
\text { contamination too. }\end{array}$ & Yes \\
\hline Nano-filtration & $60 \%$ to $90 \%$ & $60 \%$ to $90 \%$ & High & High & $\begin{array}{l}\text { No sludge disposal } \\
\text { problem }\end{array}$ & Yes \\
\hline
\end{tabular}

\section{CONCLUSION:}

The accumulation of arsenic in drinking water from different sources plays an important role in water pollution and this is a major worldwide problem. Arsenic has created health problems around the world; arsenic has been documented in the Americas, Africa, Asia, Europe and Pacific countries. Bangladesh, India, Nepal and North American countries are having severe condition of arsenic contamination. Many Governments and WHO had made several efforts to improve the condition of contaminated groundwater and its severe effect on human health. But as Bangladesh is highly mass infected, this problem is not in control here and it is going bad day by day. Among different types of sources anthropogenic sources are getting more effective day by day in modern ways of development throughout the world. Arsenic enters in the human body by direct consumption of drinking water contaminated by arsenic and the indirect intake through foods and crops cultivated using arseniccontaminated water. For arranging safe drinking water, it is required to mitigate of arsenic from the water source. The conventional arsenic mitigation technologies include oxidation (biological and chemical), adsorption, ion exchange resin, membrane processes, co-precipitation and bacterial treatment. Most of these technologies for mitigation of arsenic involve the direct mitigation of $\mathrm{As}(\mathrm{V})$ or converting $\mathrm{As}(\mathrm{III})$ to $\mathrm{As}(\mathrm{V})$ followed by mitigation of As(V). Many water purifier manufacturing companies are using reverse osmosis due to its high efficiency. But in case of mass infected people, it seems that it is unable to fulfill the requirement. However, more research is required to evaluate the practicability and feasibility of these treatment processes as well as to lower the expenses of treatment. The government should monitor and document industrial and agricultural activities as they brought the arsenic pollution issue to the bodies of water in the first place. There should analysis of the discharge from industrial plants, which aim to supply safe drinking water to people in rural areas. The government should take steps and put restrictions about the handling of industrial waste. Investment should be employed on the great engineering system for water transportation and documentation of water quality.

\section{ACKNOWLEDGEMENTS:}

The authors gratefully acknowledge the financial supports of the Bangladesh Council of Scientific and Industrial Research (BCSIR) by providing "D. Abdullah Al Muti-Shorfuddin Memorial Fellowship". The authors' are thankful to INARS, BCSIR for providing technical support and facilities.

\section{CONFLICT OF INTEREST:}

The Authors declares that there is no potential conflict of interest.

\section{REFERENCES:}

1. Abedin, M. J., Cresser, M. S., and CotterHowells, J., (2002). Arsenic accumulation and metabolism in rice (Oryza sativa L.). Environmental Chemical Engineering, 36, pp. 962968. https://doi.org/10.1021/es0101678 
2. Ahluwalia, S. S., and Goyal, D. (2005). Removal of heavy metals from waste tea leaves from aqueous solution. J. of Engineering in Life Sciences, 5(2), pp.158-162. https://doi.org/10.1002/elsc.200420066

3. Ahmad, A., Richards, L.A. and Bhattacharya, P. (2017). Arsenic remediation of drinking water: an overview, in: P. Bhattacharya, D.A. Polya, D. Jovanovic (Eds.), Best Practice Guide on the Control of Arsenic in Drinking Water, IWA Publishing, London, pp. 79-98. https://doi.org/10.2166/9781780404929 079

4. Ahmad T, Uddin ME, Alam MK, Moniruzzaman M, Saha B, Alam M. G, Hossain I. (2018). Evaluation of Microbial and Physiochemical Properties of Three Selected Lakes Water in Dhaka City, Bangladesh. Scholars Academic J. of Biosci., 6(2): 230-238. https://doi.org/10.21276/sajb.2018.6.2.17

5. Ahmed, M. F., Ahuja, S., Alauddin, and Van Geen, A. (2006). Ensuring safe drinking water in Bangladesh. Sci., 314(5806), 1687-1688.

6. Ahn, J. S. (2012). Geochemical occurrences of arsenic and fluoride in bedrock groundwater: A case study in Geumsan County, Korea. Environmental and Geochemistry Health, 34, 43-54. https://doi.org/10.1007/s10653-011-9411-5

7. Alarcón-Herrera, M.T., Bundschuh, J., Nath, B., and Sracek, O. (2013). Co-occurrence of arsenic and fluoride in groundwater of semiarid regions in Latin America: Genesis, mobility and remediation. J. of Hazardous Material. 262, pp. 960-969. https://doi.org/10.1016/j.jhazmat.2012.08.005

8. Andrianisa, H. A., Ito, A., Sasaki, A., Aizawa, J. and Umita, T. (2008). Biotransformation of arsenic species by activated sludge and removal of bio-oxidized arsenate from waste water by coagulation with ferric chloride. Water Research. 42, pp. 4809-4817. https://doi.org/10.1016/j.watres.2008.08.027

9. Anjum, A.; Lokeswari, P.; Kaur, M.; Datta, M. (2011). Removal of As(III) from aqueous solution using montmorillonite. Journal of Chromatography. B, 1, 25-30.

http://dx.doi.org/10.4236/jasmi.2011.12004
10. Armienta, M. A. and Segovia, N. (2008). Arsenic and fluoride in the groundwater of Mexico. Environ., and Geochem. Heal., 30, 345-353. http://dx.doi.org/10.1007/s10653-008-9167-8

11. Asadullah, M. N. and Chaudhury, N. (2011). Poisoning the mind: arsenic contamination of drinking water wells and children's educational achievement in rural Bangladesh. Economics Edu. Review. 30(5), pp. 873-888.

12. Asere, T. G., Christian, V., Stevens and Laing, G. D. (2019). Use of (modified) natural adsorbents for arsenic remediation: A review. Sci. of the Total Environment, 676, 706-720. https://doi.org/10.1016/j.scitotenv.2019.04.237

13. BAMWSP, DFID and Water Aid Bangladesh (2001), Rapid Assessment of Household Level Arsenic Removal Technologies, Phase-I and Phase-II, Final Report, WS Atkins International Limited.

14. Banerjee, K., Amy, G., Prevost, M., and Blumenschein, C. (2008). Kinetic and thermodynamic aspects of adsorption of arsenic onto granular ferric hydroxide (GFH). Water Research. 42, pp. 3371-3378. https://doi.org/10.1016/j.watres.2008.04.019

15. Banerji T and Chaudhari S. (2016). Arsenic removal from drinking water by electrocoagulation using iron electrodes-an understanding of the process parameters. J. of Environ. Chem. Engin.. 4(4), pp. 3990-4000. https://doi.org/10.1016/j.jece.2016.09.007

16. Bang, S., Patel, M., Lippincott, L. and Meng. X. (2005.). Removal of arsenic from ground water by granular titanium dioxide adsorbent. Chemosphere, 60(3), pp. 389-397. https://doi.org/10.1016/j.chemosphere.2004.12.008

17. Basha, S., Murthy, Z. V. P. and Jha, B. (2008). Biosorption of hexavalent chromium by chemically modified seaweed, Cystoseira indica. J. of Chemical Engin..137, pp. 480488. https://doi.org/10.1016/j.cej.2007.04.038

18. Baskan, M. B., and Pala, A. (2010). A statistical experiment design approach for arsenic removal by coagulation process using aluminum sulfate, Desalination. 254(1-3), pp. 42-48. 
19. Bayatkashkoli, A., Ravan, S. and Shamsian, M. (2017). Comparing of performance of treated particleboard with alkaline copper quat, boron-fluorine-chromium-arsenic and Chlorotalonil against Microcerotermes diver-sus and Anacanthotermesvagans termite. Intern. Biodeterioration and Biodegradation, 120, pp. 186-191.

https://doi.org/10.1016/j.ibiod.2017.03.003

20. Berg, M., Stengel, C., Pham, T. K. T., and Fredericks, D. (2007). Magnitude of arsenic pollution in the Mekong and Red River Deltas Cambodia and Vietnam. Science of Total Environment, 372, pp. 413-25.

https://doi.org/10.1016/j.scitotenv.2006.09.010

21. Bhowmick, S., Pramanik, S., Singh, P., and Nriagu, J., (2018). Arsenic in groundwater of West Bengal, India: A review of human health risks and assessment of possible intervention options. Science of the Total Environment, 612, pp. 148-169.

22. Bose, R. and De, A. (2013). Arsenic contamination: unavoidable natural phenomenon or an anthropogenic crisis. Proceedings of National Academy of Sciences, India Section A: Physical Sciences, 83, pp. 181 -185. https://doi.org/10.1007/s40010-013-0072-x

23. Brandhuber, P. and Amy, G. (2001). Arsenic removal by charged ultrafiltration membrane influences of membrane operating conditions and water quality on arsenic rejection. Desalination. 140, pp. 1-14. https://doi.org/10.1016/S0011-9164(01)00350-2

24. British Geological Survey (BGS) and Dept. of Public Health Engineering (DPHE). (2001). Arsenic contamination of groundwater in Bangladesh. Final report (Feb. 2001). Dhaka: British Geological Survey and Dept. of Public Health Engineering.

25. Chakraborti, D., Rahman, M.M., Mukherjee, A., and Hossain, M.M. (2015). Groundwater arsenic contamination in Bangladesh-21 Years of research. J. of Trace Elements in Medicine and Biology.31, pp. 237-248.

https://www.sciencedirect.com/science/article/ab s/pii/S0946672X15000048
26. Chang, Q., Lin, W. and Ying, W. C. (2010). Preparation of iron-impregnated granular activated carbon for arsenic removal from drinking water. J. of Hazardous Materials, 184 (1), pp. 515-22.

https://doi.org/10.1016/j.jhazmat.2010.08.066

27. Charlet, L.,Chakraborty, S., and Appelo C. A. J. (2007). Chemodynamics of an arsenic "hotspot" in a West Bengal aquifer: a field and reactive transport modeling study. J. of Appl. Geochemistry. 22(7), pp. 1273-1292. https://doi.org/10.1016/j.apgeochem.2006.12.022

28. Choong, T.S.Y., Chuah, T., Robiah, Y., and Azni, I., (2007). Arsenic toxicity, health hazards and removal techniques from water: an overview. Desalination, 217, pp. 139-166. https://doi.org/10.1016/j.desal.2007.01.015

29. Chowdhury, M.T.A., Deacon, C.M., Steel, E., and Norton, G.J. (2018). Physiographical variability in arsenic dynamics in Bangladeshi soils. Science of Total Environment, 612, pp. 1365-1372. https://doi.org/10.1016/j.scitotenv.2017.09.030

30. Chutia, P., Kato, S., Kojima, T. and Satokawa, S. (2009). Arsenic adsorption from aqueous solution on synthetic zeolites. Journal Hazardous Materials. 162, pp. 440-447.

31. Cundy, A.B., Hopkinson, L. and Whitby, R.L.D. (2008). Use of iron-based technologies in contaminated land and groundwater remediation: a review. Science of the Total Environment. 400, pp. 42-51. https://doi.org/10.1016/j.scitotenv.2008.07.002

32. Das, N., Das, A., Sarma, K.P. and Kumar, M.(2018). Provenance, prevalence and health perspective of co-occurrences of arsenic, fluoride and uranium in the aquifers of the Brahmaputra River floodplain. Chemosphere 194, pp. 755.772.

https://doi.org/10.1016/j.chemosphere.2017.12.021

33. Daus, B., Wennrich, R., and Weiss, H. (2004). Sorption materials for arsenic removal from water: a comparative study. Journal of Water Research. 38, pp. 2948-2954.

https://doi.org/10.1016/j.watres.2004.04.003

34. Deng, S., Zhang, G.S., Chen, S.W., and Wang, P. (2016). Rapid and effective preparation of a 
HPEI modified biosorbent based on cellulose fiber with a microwave irradiation method for enhanced arsenic removal in water. J. of Mat. Chemistry, 4, 15851-15860. https://doi.org/10.1039/C6TA06051J

35. Dodd M. C., Vu N. D, Ammann A. (2006). Kinetics and mechanistic aspects of As(III) oxidation by aqueous chlorine, chloramines, and ozone: relevance to drinking water treatment. Environ. Sci., and Techno-l., 40(10), 3285-3292. https://doi.org/10.1021/es0524999

36. Dong, L., Zinin, P. V., Cowen, J. P. and Ming, L. C. (2009). Iron coated pottery granules for arsenic removal from drinking water. Journal of Hazardous Materials. 168(2), pp. 626-32. https://doi.org/10.1016/j.jhazmat.2009.02.168

37. Dutta, P. K., Ray, A. K., and Millero, F. J. (2004). Adsorption of arsenate and arsenite on titanium dioxide suspensions. J. of Colloid and Interface Science, 278(2), pp. 270-275. https://doi.org/10.1016/j.jcis.2004.06.015

38. Ekhlas Uddin Md., Pulak Maitra, and Firoz Alam Md., (2014). Isolation and characterization of proteases enzyme from locally isolated Bacillus sp., American Journal of Life Sciences. 2(6), 338-344. https://doi.org/10.11648/j.ajls.20140206.12

39. Engel, R. R. and Smith, A. H. (2004) Arsenic in drinking water and mortality from vascular disease: an ecologic analysis in 30 countries in the United States. Archives of Environmental Health, 49(5), pp. 418-427. https://doi.org/10.1080/00039896.1994.9954996

40. Ferlay, J., Soerjomataram, I., Dikshit, R., Eser, S., and Bray, F. (2015). Cancer incidence and mortality worldwide: sources, methods and major patterns in GLOBOCAN 2012. Intern. J. of Cancer, 136(5), 359-86.

https://doi.org/10.1002/ijc.29210

41. Figoli, A., Cassano, A., Criscuoli, A., and M.A., Drioli, E. (2010). Influence of operating parameters on the arsenic removal by nanofiltration. Water research.44, pp. 97-104. https://doi.org/10.1016/j.watres.2009.09.007

42. Fontcuberta, M., Calderon, J., and Nebot, M. (2011). Total and inorganic arsenic in marketed food and associated health risks for $\backslash$ the Catalan (Spain) population. J. of Agri. and Food Chem. 59, pp. 10013-10022.

https://doi.org/10.1021/jf2013502

43. Freikowski, D., Neidhardt, H., Winter, J., Berner, Z. and Gallert, C. (2013). Effect of carbon sources and of sulfate on microbial arsenic mobilization in sediments of West Bengal, India. Ecotoxicology abd Environmental Safety. 91, pp. 139-146. https://doi.org/10.1016/j.ecoenv.2013.01.021

44. Gallegos-Garcia M., Ramírez-Muñiz K. and Song, S. (2012). Arsenic removal from water by adsorption using iron oxide minerals as adsorbents: a review. Mineral Processing and Extractive Metallurgy Review, 33(5), 301-15. https://doi.org/10.1080/08827508.2011.584219

45. Garg, U. K., Kaur, M. P., Garg, V. K., and Suda, D. (2007). Removal of hexavalent chromium from aqueous solution by agricultural waste biomass. J. of Haz. Mat., 140, 60-68.

46. Gentry, P. R., McDonald, T. B., and Clewell III, H.J.(2010). Analysis of genomic doseresponse information on arsenic to inform key events in a mode of action for carcinogenicity. $J$. of Environmental and Molecular Mutagenesis, 51(1), pp. 1-14. https://doi.org/10.1002/em.20505

47. Giménez, J., dePablo, J., and Valderrama, C. (2010). Reactive transport of arsenic(III) and arsenic(V) on natural hematite: experimental and modeling. J.of Colloid Interface Science. 348, pp. 293-297. https://doi.org/10.1016/j.jcis.2010.04.046

48. Golami, M., Mohammadi, H. A. and Mokhtari, S. A. (2009). Application of reverse osmosis technology for arsenic removal from drinking water. Zanzan University of Medical Science Journal, 17(68), pp. 9-20. https://doi.org/10.1089/ees.2007.24.113

49. Guan, X., Du, J., Meng, X., and Hu, Q. (2012). Corrigendum to Application of titanium dioxide in arsenic removal from water: a review. J. of Hazard. Materials, 221- 222, 303. https://doi.org/10.1016/j.jhazmat.2012.02.069

50. Gueye, M. T., Palma, L. D., and Vilardi, G.(2016). The influence of heavy metals and organic matter on hexavalent chromium redu- 
ction by nano zero valent iron in soil. $J$. of Chemical Engin. Transaction. 47, 289-294. https://doi.org/10.3303/CET1647049

51. Guo, H., Zhang, B., Li, Y., Berner, Z., and Stuben, D. (2011). Hydrogeological and biogeochemical constrains of arsenic mobilezation in shallow aquifers from the Hetao basin, Inner Mongolia. J. of Environmental Pollution, 159(4), 876-883. https://doi.org/10.1016/j.envpol.2010.12.029

52. Haque, M., Morrisson, G., and GardeaTorresdey, J. (2007). Characteristics of arsenic adsorption to sorghum biomass. J. Hazardous Materials.145, pp. 30-45. https://doi.org/10.1016/j.jhazmat.2006.10.080

53. Haque, S. and Johannesson, K.H. (2006). Arsenic concentrations and speciation along a groundwater flow path: the Carrizo Sand aquifer. Texas, USA. Chemical geology, 228 (1-3), pp.57-71.

54. Hossain, M. (2006). Arsenic contamination in Bangladesh: an overview. Agriculture Ecosystem Environment, 113, pp. 1-16. http://doi.org/10.1016/j.agee.2005.08.034

55. Howladar, M.F. (2017). An assessment of surface water chemistry with its possible sources of pollution around the Barapukuria Thermal Power Plant Impacted Area, Dinajpur, Bangladesh. Ground water for Sustainable Development, 5, pp. 38-48.

https://doi.org/10.1016/j.gsd.2017.03.004

56. Hu, C., Liu, H., Chen, G. and Qu, J. (2012). Effect of aluminum speciation on arsenic removal during coagulation process. Separation and Purification Technol., 86, 35-40.

57. Huq, S. M. I., Joardar, J. C., Naidu, R. (2006). Arsenic conta-mination in food chain: transfer of arsenic into food materials through groundwater irrigation. J. of Health Population and Nutrition, 24(3), pp. 305-316.

58. Iervolino, G., Vaiano, V., and Sannino, D. (2016). Removal of arsenic from drinking water by photo-catalytic oxidation on $\mathrm{MoO}_{\mathrm{x}} /$ $\mathrm{TiO}_{2}$ and adsorption on $\gamma-\mathrm{Al}_{2} \mathrm{O}_{3}$. J. of Chemical Technology and Biotechnology. 91(1), 88-95. https://doi.org/10.1002/jctb.4581
59. Iqbal, J., Kim, H.J., Baek, K. and Yang, J.W. (2007). Removal of arsenic from groundwater by micellar-enhanced ultra filtration (MEUF). Chemosphere. 66, 970-976. https://doi.org/10.1016/j.chemosphere.2006.06.005

60. Islam, A. M. (2004). Membrane distillation process for pure water and removal of arsenic. Master of Science thesis for International Master's Program in Applied Environmental Measurement Technique.

61. Islam, S. D. U., Majumder, R. K., and Alam, M. F. (2017). Hydrochemical characteristics and quality assessment of groundwater in patuakhali district, southern coastal region of Bangladesh. Exposure and health, 9, 43-60. https://link.springer.com/article/10.1007/s12403016-0221-y

62. Israt, J. M., Lotin, A. M., Moniuzzaman, M. and Sadullah, M. A.(2008). Arsenic removal from water using activated carbon obtained from chemical activation of jute stick. Indian J. of Chemical Technology.15, pp. 413-416. http://nopr.niscair.res.in/handle/123456789/2825

63. Jain, C.K. and Singh, R.D. (2012). Technological options for the removal of arsenic with special reference to South East Asia. J. of Environmental Management, 107, pp. 1-18. https://doi.org/10.1016/j.chemgeo.2005.11.019

64. Jang, M., Chen, W. and Cannon, F.(2008). Preloading hydrous ferric oxide into granular activated carbon for arsenic removal. Environmental Science and Technology. 42, pp. 33693374. https://doi.org/10.1021/es7025399

65. Jomova, K., Jenisova, Z., Feszterova, and Valko, M. (2011). Arsenic: toxicity, oxidative stress and human disease. J. of Applied Toxicology, 31 (2), pp. 95-107. https://doi.org/10.1002/jat.1649

66. Katsoyiannis, I. A., Zouboulis, A. I. and Jekel, M. (2004). Kinetics of bacterial As(III) oxidation and subsequent $\mathrm{As}(\mathrm{V})$ removal by sorption onto biogenic manganese oxides during groundwater treatment. Industrial and Engineering Chemistry Research, 43(2), pp. 486-493. https://doi.org/10.1021/ie030525a

67. Khairul, I., Wang, Q. Q., Jiang, Y. H., Wang, C. and Naranmandura, H. (2017). Metabolism, 
toxicity and anticancer activities of arsenic compounds. Oncotarget, 8(14), 23905-23926.

68. Khan, S. I., Ahmed, A. K. M., and Wahed, M. A. (2010). Arsenic and cadmium in food-chain in Bangladesh - an exploratory study. $J$. of Heal. Popul. and Nutr., 28(6), 578-584. https://doi.org/10.3329/jhpn.v28i6.6606

69. Khosa, M.A.; Ullah, A. (2014). In-situ modification, regeneration, and application of keratin biopolymer for arsenic removal. $J$. Hazardous Materials. 278, pp. 360-371. https://doi.org/10.1016/j.jhazmat.2014.06.023

70. Kim, S.-H., Kim, K., Ko, K.-S., and Lee, K.-S. (2012). Co-contamination of arsenic and fluoridein the groundwater of unconsolidated aquifers under reducing environments. Chemosphere, 87, pp. 851-6. https://doi.org/10.1016/j.chemosphere.2012.01.025

71. Lacasa, E., Ca nizares, P., S'aez, C., and Rodrigo, M. A. (2011): Removal of arsenic by iron and aluminium electrochemically assisted coagulation. J. of Separation and Purification Technology. 79(1), pp. 15-19. https://doi.org/10.1016/j.seppur.2011.03.005

72. Lakshmanan, D., Clifford, D. A. and Samanta, G. (2010). Comparative study of arsenic removal by iron using electrocoagulation and chemical coagulation. J. of Water Research, 44(19), pp. 5641-5652. https://doi.org/10.1016/j.watres.2010.06.018

73. Lara, F., Cornejo, L., and Mansilla, H.D., (2006). Solar light assisted removal of arsenic from natural waters: effect of iron and citrate concentrations. J. of Chemical Technology and Biotechnology, 81, pp. 1282-1287. https://doi.org/10.1002/jctb.1547

74. Lee Y., Um I.-H., and Yoon, J. (2003). Arsenic (III) oxidation by iron (VI) (ferrate) and subsequent removal of arsenic (V) by iron (III) coagulation. Environmental Science and Technology, 37(24), pp. 5750-5756. https://doi.org/10.1021/es034203

75. Leupin O. X., and Hug, S. J. (2005). Oxidation and removal of arsenic (III) from aerated groundwater by filtration through sand and zero-valent iron. Water Research, 39(9), pp. 1729-1740.
76. Lin, T.Y., Hafeznezami, S., Rice, L., and Suffet, I. M. (2017). Arsenic oxyanion binding to NOM from dung and aquaculture pond sediments in Bangladesh: importance of sitespecific binding constants. J. of Applied Geochemistry, 78, pp. 234-240. https://doi.org/10.1016/j.apgeochem.2016.12.026

77. Liu, Y.-Y., Leus, K., Grzywa, M., van der Voort, P. (2012). Synthesis, structural characterization and catalytic performance of a vanadium-based metal-organic framework (COMOC-3). European Journal Inorganic Chemistry. 2819-2827. https://doi.org/10.1002/ejic.201101099

78. Malkoc, E., and Nuhoglu, Y. (2007). Potential of tea factory waste for chromium (VI) removal from aqueous solutions. Thermodynamic and kinetic studies. J. of Separation of Purification Technology. 54, 291-298. https://doi.org/10.1016/j.scitotenv.2011.08.051

79. Meher, A. K., Das, S., and Bansiwal, A. (2015). Enhanced arsenic removal from drinking water by iron-enriched aluminosilicate adsorbent prepared from fly ash. Desalination and Water Treatment, pp. 1-3. https://doi.org/10.1080/19443994.2015.1112311

80. Memon, S.Q., Bhanger, M.I. and Memon, J.Ur-R. (2008). Evaluation of banana peel for treatment of arsenic contaminated water. Proceeding of the $1^{\text {st }}$ Technical Meeting of Muslim Water Researchers Cooperation. pp. 104-109.

81. Miller, S. M., Spaulding, M. L. and Zimmerman, J. B. (2011). Optimization of capacity and kinetics for a novel bio-based arsenic sorbent, $\mathrm{TiO}_{2}$-impregnated chitosan bead. Water Research, 45(17), 5745-5754. http://doi.org/10.1016/j.watres.2011.08.040

82. Mondal P., Bhowmick S., and Van der Bruggen B. (2013). Remediation of inorganic arsenic in groundwater for safe water supply: a critical assessment of technological solutions. Chemosphere, 92 (2), pp. 157-170. https://doi.org/10.1016/j.chemosphere.2013.01.097

83. Muhammad, S., Shah, M.T. and Khan, S., (2010). Arsenic health risk assessment in drinking water and source apportionment using 
multivariate statistical techniques in Kohistanregion, northern Pakistan. Food and Chemical Toxicology, 48 (10), 2855-2864. https://doi.org/10.1016/j.fct.2010.07.018

84. NGOs Arsenic Information \& Support Unit (NAISU). Arsenic (2002). An overview of arsenic issues and mitigation initiatives in Bangladesh.

85. Nicolli, H. B., Bundschuh, J., and Jean, J.S. (2010). Sources and controls for the mobility of arsenic in oxidizing ground waters from loess-type sediments inarid/semi-arid dry climatese Evidence from the Chacoe Pampean plain (Argentina). Water research, 44, pp. 5589-5604.

https://doi.org/10.1016/j.watres.2010.09.029

86. Nicomel, N R., Leus,K., Folens, K., and Laing, G. D. (2016). Technologies for Arsenic Removal from Water: Current Status and Future Perspectives. Inter. J. of Environ. Res., and public health, 13, pp. 62.

https://doi.org/10.3390/ijerph13010062

87. Nriagu, J., Bhattacharya, P., and Loeppert, R. (2007). Arsenic in soil and groundwater: an overview. Elsevier, Amsterdam, pp. 3-60.

88. Oehmen, A., Viegas, R., Velizarov, S., and Crespo, J. G. (2006). Removal of heavy metals from drinking water supplies through the ion exchange membrane bioreactor. Desalination, 199, pp. 405-407.

https://doi.org/10.1016/j.desal.2006.03.091

89. Oremland, R. S., Saltikov, C. W., and Stolz,J. F. (2009). Arsenic in the evolution of earth and extraterrestrial eco-systems. Geomicrobiology J., 26(7), 522-536. https://doi.org/10.1080/01490450903102525

90. Pallier, V., Feuillade-Cathalifaud, G., and Bollinger, J.-C. (2010). Effect of organic matter on arsenic removal during coagulation/ flocculation treatment. J. of Colloid and Interface Science, 342(1), pp. 26-32. https://doi.org/10.1016/j.jcis.2009.09.068

91. Patel, A.K., Das, N., Goswami, R. and Kumar, M. (2019). Arsenic mobility and potential coleaching of fluoride from the sediments of three tributaries of the Upper Brahmaputra flood plain, Lakhimpur, Assam, India. J. of Geochemical Exploration, 203, pp.45-58. https://doi.org/10.1016/j.gexplo.2019.04.00483

92. Petrick, J.S., Ayala-Fierro, F., Cullen, W.R., and Aposhian, H.V. (2000). Monomethylarsonous acid (MMAIII) is more toxic than arsenite in Chang human hepatocytes. Toxicology and Applied Pharmacology, 163, pp. 203-207.

93. Pinheiro, B. S., Gimenes, L.L., and Freschi, G.P.G. (2016). Arsenic speciation in environmental samples using different acid concentrations and ultrasonic extraction for the determination by HG-FAAS. Atomic Spectroscopy. 37, pp. 83-89.

https://doi.org/10.1080/10934529.2017.1340749

94. Polizzotto, M. L., Lineberger, E. M., Matteson, A. R., and Ali, M. A. (2013). Arsenic transport in irrigation water across rice-field soils in Bangladesh. Environmental pollution, 179, pp. 210-217.

https://doi.org/10.1016/j.envpol.2013.04.025

95. Radloff, K.A., Zheng, Y., Stute, M., and van Geen, A. (2017). Reversible adsorption and flushing of arsenic in a shallow, Holocene aquifer of Bangladesh. J. of Applied Geochemistry, 77, pp.142-157.

https://doi.org/10.1016/j.apgeochem.2015.11.003

96. Ranjan, D., Talat, M. and Hasan, S. (2009). Biosorption of arsenic from aqueous solution using agricultural residue 'ricepolish'. $J$. Hazardous Materials. 166, pp. 1050-1059. https://doi.org/10.1016/j.jhazmat.2008.12.013

97. Reza, A.S. and Jean, J. S. (2012). Vertical distribution and mobilization of arsenic in shallow alluvial aquifers of Chapai-Nawabganj district, Northwestern Bangladesh. $J$. of Geological Society of India, 80, 531-538. https://doi.org/10.1007/s12665-012-1825-6

98. Saitua, H., Campderros, M., Cerutti, S. and Padilla, A.P. (2005). Effect of operating conditions in removal of arsenic from water by nanofiltration membrane. Desalination. 172, pp. 173-180. https://doi.org/10.1016/j.desal.2004.08.027

99. Sanjrani, M. A., Zhou, B., Zhao, H, and Xia, S. B. (2019). Arsenic contaminated groundwater 
in China and its treatment options, a review. Applied Ecology and Environmental Research, 17(2), 1655-1683. http://dx.doi.org/10.15666/aeer/1702_16551683 100. Santra, S. C., Samal, A. C., Bhattacharya, P., and Majumdar, J. (2013). Arsenic in food chain and community health risk: a study in gangetic west Bengal. Procedia Environmental Sciences. Proceedings of the International Symposium on Enviro-nmental Science and Technology 18, pp. 2-13. https://doi.org/10.1016/j.proenv.2013.04.002

101. Sasaki, K., Nakano, H., Wilopo, W., Miura, Y., Hirajima, T. (2009). Sorption and speciation of arsenic by zero-valent iron. Colloids and Surfaces A: Physicochemical Engineering Aspects. 347, pp. 8-17.

https://doi.org/10.1016/j.colsurfa.2008.10.033

102. Sawalha, M. F., Torresdey, G., and Peralta-Vide, J. R. (2005). Determination of adsorption and speciation of chromium species by saltbush (Atriplex canescens) biomass using a combination of XAS and ICP-OES. Microchemical J. 81, 122-132.

https://doi.org/10.1016/j.microc.2005.01.008

103. Seidel, A., Waypa, J.J. and Elimelech, M. (2001). Role of charge (Donnan) exclusion in removal of arsenic from water by a negatively charged porous nanofiltration membrane. Environ. Engin. Sci. 18, 105-113. https://doi.org/10.1089/10928750151132311

104. Shah, B.A. (2012). Role of Quarternary stratigraphy on arsenic-contaminated ground water from parts of Barak Valley, Assam, North-East India. Environmental Earth Sciences. 66, pp. 2491-2501. https://doi.org/10.1007/s12665-011-1472-3

105. Shakoor, M. B., Nawa, R., Hussain, F., Raza, M. and Ali, S. (2017). Human health implications, risk assessment and remediation of As-contaminated water: a critical review. Science of Total Environment, 601(602), pp. 756-769.

https://doi.org/10.1016/j.scitotenv.2017.05.223

106. Shankar, S., Shanker, U. and Shikha. (2014). Arsenic contamination of ground water: a review of sources, prevalence, health risks, and strategies for mitigation. Scientific World Journal, 2014(304524), 1-18.

https://www.hindawi.com/journals/tswj/2014/30 4524/

107. Sharma, V. K., Dutta, P. K. and Ray, A. K. (2007). Review of kinetics of chemical and photocatalytical oxidation of Arsenic (III) as influenced by $\mathrm{pH}$. J. of Environmental Science and Health, 42(7), 997-1004. https://doi.org/10.1080/10934520701373034

108. Sheng, P.X., Ting, Y., Chen, J. P., and Hong, L. (2004). Sorption of lead, copper, cadmium, zinc and nickel by marine algal biomass: characterization of biosorptive capacity and investigation of mechanisms. J. of Colloid Interface Science, 275, 131-141. https://doi.org/10.1016/j.jcis.2004.01.036

109. Shih, M.C. (2005). An overview of arsenic removal by pressure driven membrane processes. Desalination. 172, pp. 85-97. https://doi.org/10.1016/j.desal.2004.07.031

$110 . \quad$ Singh, R., Singh, S., and Prasad, S.M. (2015). Arsenic contamination, consequences and remediation techniques: a review. Ecotoxicology and Environmental Safety, 112, pp. 247-270.

https://www.sciencedirect.com/science/article/ab s/pii/S0147651314004746

111. Smith, A. H., Lingas, E. O. and Rahman, M. (2000) Contamination of drinking-water by arsenic in Bangladesh: a public health emergency. Bulletine of World Health Organization. 78(9), pp. 1093-1103. https://doi.org/10.1016/j.envint.2008.07.015

112. Sohel, N., Vahter, M., Ali, M., and Persson, L. A. (2010). Spatial patterns of fetal loss and infant death in an arsenic-affected area in Bangladesh (Paper No.53). Intern. J. of Health Geographics, 53(9), 11. https://doi.org/10.1186/1476-072x-9-53

113. Su, C., Zhu, Y., Abbas, Z. and Huq, M.E. (2016). Sources and controls for elevated arsenic concentrations in ground-water of Datong Basin, Northern China. Environmental Earth Science, 75, pp. 1-13. https://doi.org/10.1007/s12665-016-5359-1 
114. Suzuki, K, T.,Kurasaki, K., and Suzuki, N. (2007). Selenocysteine $\beta$-lyase and methylselenol demethylase in the metabolism of Se-methylated selenocompounds into selenide. J. of Biochmica et Biophysica Acta. 1770(7), pp. 1053-1061.

https://doi.org/10.1016/j.bbagen.2007.03.007

115. Tripathy, S. S. and Raichur, A. M. (2008). Enhanced adsorption capacity of activated alumina by impregnation with alum for removal of $\mathrm{As}(\mathrm{V})$ from water. Chemical Engineering Journal, 138, pp. 179-186. https://doi.org/10.1016/j.cej.2007.06.028

$116 . \quad$ Uddin, M., Mozumder, M., Islam, M., Deowan, S., and Hoinkis, J. (2007). Nanofiltration membrane process for the removal of arsenic from drinking water. J. of Chemical Engineering Technology, 30, pp. 1248-1254. https://doi.org/10.1002/ceat.200700169

117. Ungureanu, G., Santos, S., Boaventura, R., and Botelho, C. (2015). Arsenic and antimony in water and waste water: overview of removal techniques with special reference to latest advances in adsorption. J. of environ. Manag., 151, 326-42.

https://doi.org/10.1016/j.jenvman.2014.12.051

118. Velizarov, S., Crespo, J. and Reis, M. (2004). Removal of inorganic anions from drinking water supplies by membrane bio/processes. Reviews in Environmental Science and Biotechnology. 3, pp. 361-380. https://doi.org/10.1007/s11157-004-4627-9

$119 . \quad$ Verma, A., Chakraborty, S., and Basu, J. K. (2006). Adsorption study of hexavalent chromium using tamarind hull-based adsorbents. J. of Separation and Purification Technology, 50, pp. 336-341. https://doi.org/10.1007/BF03326009

120. Verma, P., Agarwal, A. and Singh. V. (2014). Arsenic Removal from Water through Adsorption-A Review. Recent Research in Science and Technology, 6(1).

https://updatepublishing.com/journal/index.php/r rst/article/view/1203

121. Walker, M., Seiler, R.L. and Meinert, M. (2008). Effectiveness of household reverseosmosis systems in a Western US region with high arsenic in groundwater. Science of Total Environment, 389, 245-252.

https://doi.org/10.1016/j.scitotenv.2007.08.061

122. Wang, J.P., Wang, S.L., and Ng, J.C., (2009). Association of arsenic and kidney dysfunction in people with diabetes and validation of its effects in rats. Environmental International, 35, pp. 507-511. https://doi.org/10.1016/j.ecoenv.2017.12.032

123. Wang, Y., Pi, K., Fendorf, S., Deng, Y. and Xie, X. (2019). Sedimentogenesis and hydro biogeochemistry of high arsenic Late Pleistocene-Holocene aquifer systems. Earth Science Reviews, 189, pp. 79-98.

124. Wen, D., Zhang, F., Zhang, E., and Zheng, Y. (2013). Arsenic, fluoride and iodine ingroundwater of China. J. of Geochemical Exploration. 135, pp. 1-21.

https://doi.org/10.1016/j.gexplo.2013.10.012

125. WHO, Guidelines for Drinking-Water Quality, (2011). World Health Organization, 4.

126. Xie, X., Wang, Y., Su, C. and Duan, M. (2013). Effects of Recharge and Discharge on $\delta 2 \mathrm{H}$ and $\delta 18 \mathrm{O}$ Composition and Chloride Concentration of High Arsenic/Fluoride Ground water from the Datong Basin, Northern China. Water Environ. Res., 85, 113-123. https://doi.org/10.2175/106143012X1337357583 $\underline{1196}$

127. Yamani, J. S., Miller, S. M., and Zimmerman, J. B. (2012). Enhanced arsenic removal using mixed metal oxide impregnated chitosan beads. Wat. Res., 46(14), 4427-4434. https://doi.org/10.1016/j.watres.2012.06.004

128. Yang, X., Hou, Q., Yang, Z., Zhang, X. and Hou, Y. (2012). Solid-solution partitioning of arsenic (As) in the paddy soil profiles in Chengdu Plain, Southwest China. Geo science Frontiers, 3, pp. 901-909. https://www.sciencedirect.com/science/article/pii /S1674987112000382

129. Yavuz, C. T., Mayo, J. T., Suchecki, C., Wang, J., and Kelty, C. (2010). Pollution magnet: nano magnetite for arsenic removal from drinking water. Environmental geochemistry and health. 32 (4), 327-334. https://doi.org/10.1007/s10653-010-9293-y 
130. Yazdani, M., Tuudjarvi, T., Bhatnagar, A., Vahala, R., (2016). Adsorptive removal of arsenic (V) from aqueous phase by feldspars: kinetics, mechanism, and thermodynamic aspects of adsorption. J. of Molecular Liquid, 214, 149-156.

131. Yoon, J., Amy, G., Chung, J., Sohn, J. and Yoon, Y. (2009). Removal of toxic ions (chromate, arsenate, and perchlorate) using reverse osmosis, nanofiltration and ultrafiltration membranes. Chemosp., 77, 228-235. https://doi.org/10.1016/j.chemosphere.2009.07.028

132. Yoshizuka, K., Nishihama, S. and Sato, H., (2010). Analytical survey of arsenic in geothermal waters from sites in Kyushu, Japan, and a method for removing arsenic using magnetite. Environmental and Geochemical Health, 32, pp. 297-302. https://doi.org/10.1007/s10653-010-9300-3

133. Yu, Q., Wang, Y., Xie, X., and Yu, M. (2015). Effects of short-term flooding on arsenic transport in groundwater system: a case study of the Datong Basin. J. Geochemical Exploration, 158, pp. 1-9.

http://dx.doi.org/10.1016/j.gexplo.2015.05.015

134. Yunus, M., Sohe,1 N., Hore, S. K. and Rahman, M. (2011). Arsenic exposure and adverse health effects: a review of recent findings from arsenic and health studies in Matlab, Bangladesh. Kaohsiung J. of Medical Science, 27(9), 371-376.

https://doi.org/10.1016/j.kjms.2011.05.012

135. Zhu, Y.G., Yoshinaga, M., Zhao, F.J. and Rosen, (2014) B.P. Earth abides arsenic biotransformations. Annual Review of Earth and Planetary Science, 42, pp. 443-467. https://doi.org/10.1146/annurev-earth-060313$\underline{054942}$

136. Zongliang, H., Senlin, T. and Ping, N. (2012). Adsorption of arsenate and arsenite from aqueous solutions by cerium-loaded cation exchange resin. Journal of Rare Earth. 30, pp. 563-572.

https://doi.org/10.1016/S1002-0721(12)60092-1

Citation: Mou SA, Kabir MH, Yasmin S, and Ahmed S. (2020). Arsenic mitigation technologies from ground water: a brief review. Am. J. Pure Appl. Sci., 2(5), 139-158.

https://doi.org/10.34104/ajpab.020.01390158 C) @ 